\title{
Heavy Metals, Trace and Major Elements in 16 Wild Mushroom Species Determined by ICP-MS
}

\author{
Gülsen Tel-Çayan ${ }^{\mathrm{a}, \mathrm{b}}$, Zain Ullah $^{\mathrm{a}}$, Mehmet Öztürk ${ }^{\mathrm{a}, *}$, Murat Yabanlic $^{\mathrm{c}}$ \\ Firat Aydin, and Mehmet Emin Duru ${ }^{\mathrm{a}}$ \\ ${ }^{a}$ Department of Chemistry, Faculty of Sciences, Mugla S1tkı Koçman University, 48000 Mugla, Turkey \\ ${ }^{b}$ Department of Chemistry and Chemical Processing Technologies, Mugla Vocational School, \\ Mugla Sitkı Koçman University, 48000 Mugla, Turkey \\ c Department of Hydrobiology, Faculty of Fisheries, Mugla Sitk1 Koçman University, 48000 Mugla, Turkey \\ ${ }^{\mathrm{d}}$ Department of Chemistry, Faculty of Sciences, Dicle University, 21280 Diyarbakır, Turkey
}

\section{INTRODUCTION}

Edible mushrooms are valued all over the world as a health food since they are low in calories, low in fat and fatty acids, and rich in proteins, vitamins, and minerals such as iron $(\mathrm{Fe})$, potassium $(\mathrm{K})$, phosphorus $(\mathrm{P})$, magnesium (Mg), manganese $(\mathrm{Mn})$, zinc ( $\mathrm{Zn})$ and calcium (Ca) $(1,2)$. However, inedible and poisonous mushrooms can be used for environmental cleaning by absorbing or chelating heavy metals. Metals, such as iron, copper, zinc, and manganese are essential metals since they play an important role in biological systems. However, taken in excess some of these essential metals, including the heavy metals, can also produce toxic effects and lead to health problems (3-5).

The 16 studied mushroom species are known to contribute to favorable biological activities (see Table I) such as antioxidant (1, 6-13), antitumor $(14,15)$, anticholinesterase $(6,13)$, anti-inflammatory (16), antimicrobial $(6,9,10$, 17-19), antihypertensive (20), immunomodulating (21), antihyperglycemic (22), pancreatic lipase inhibitor (23), tyripsin inhibitor (24), nematicidal (25), $\alpha$-amylase inhibitor and $\alpha$-glucosidase inhibitor (26), antiproliferative (27) and antidiabetic activities (28).

The aim of this study was to determine the concentrations of eight minerals $(\mathrm{Na}, \mathrm{Mg}, \mathrm{Ca}, \mathrm{V}, \mathrm{Mn}$,

*Corresponding authors.

E-mail: mebmetozturk@mu.edu.tr E-mail: mebmetsadettin@gmail.com Tel: +902522113138

Fax: +902522111472

\section{ABSTRACT}

Eight minerals $(\mathrm{Na}, \mathrm{Mg}, \mathrm{Ca}, \mathrm{V}$, $\mathrm{Mn}, \mathrm{Fe}, \mathrm{Zn}, \mathrm{Se}$ ) and eight heavy metals ( $\mathrm{Al}, \mathrm{Cr}, \mathrm{Ni}, \mathrm{As}, \mathrm{Sr}, \mathrm{Co}, \mathrm{Cu}$, $\mathrm{Pb}$ ) were studied in 16 wild mushroom species: Agaricus bisporus, Agaricus bitorquis, Agaricus essettei, Armillaria tabescens, Craterellus cornucopioides, Hebeloma eburneum, Hebeloma fragilipes, Hypholoma fasciculare, Lepista nuda, Leucoagaricus leucothites, Melanoleuca graminicola, Omphalotus olearius, Phellinus torulosus, Ramaria flava, Russula foetens, and Trametes versicolor collected from Usak, Turkey, using ICP-MS. The mineral content of the mushroom samples was determined by ICPMS and ranged from 46-1717 $\mathrm{mg} / \mathrm{kg}$ for $\mathrm{Na}, 122-1121 \mathrm{mg} / \mathrm{kg}$ for $\mathrm{Mg}, 15-316 \mathrm{mg} / \mathrm{kg}$ for $\mathrm{Ca}$, $0.09-1.04 \mathrm{mg} / \mathrm{kg}$ for $\mathrm{V}, 3.60-76.40$ $\mathrm{mg} / \mathrm{kg}$ for $\mathrm{Mn}, 17.3-395 \mathrm{mg} / \mathrm{kg}$ for $\mathrm{Fe}, 3.4-70.7 \mathrm{mg} / \mathrm{kg}$ for $\mathrm{Zn}$, $0.03-0.56 \mathrm{mg} / \mathrm{kg}$ for Se. The heavy metals contents in the mushroom species were between 108-575 mg/kg for Al, 0.08-0.61 $\mathrm{mg} / \mathrm{kg}$ for $\mathrm{Cr}, 0.18-3.95 \mathrm{mg} / \mathrm{kg}$ for $\mathrm{Ni}, 0.19-4.43 \mathrm{mg} / \mathrm{kg}$ for $\mathrm{As}$, $2.41-14.9 \mathrm{mg} / \mathrm{kg}$ for $\mathrm{Sr}, 0.02-3.44$ $\mathrm{mg} / \mathrm{kg}$ for Co, $0.17-9.89 \mathrm{mg} / \mathrm{kg}$ for $\mathrm{Cu}, 0.05-3.33 \mathrm{mg} / \mathrm{kg}$ for $\mathrm{Pb}$. All values of the inedible mushrooms, except the $\mathrm{Cr}$ and $\mathrm{Pb}$ concentrations of Leucoagaricus leucothites, were within the permitted WHO limits. Thus, the mushrooms analyzed are safe for human consumption.

$\mathrm{Fe}, \mathrm{Zn}$, and Se) and eight heavy metals (Al, Cr, Ni, As, Sr, Co, Cu, and $\mathrm{Pb}$ ) in 16 mushrooms collected in the area of Usak, Turkey, using inductively coupled plasma mass spectrometry (ICP-MS). The mushroom species of Hebeloma eburneum, Hebeloma fragilipes, and Melanoleuca graminicola have, to our knowledge, never been studied. Various reports have been published on the other 13 mushroom species $(3,29,30-50)$ but some of the metals have not yet been investigated such as V, Al, As, $\mathrm{Sr}$ for $A$. bisporus; Na, V, Cr, As, Sr, Co for A. bitorquis; $\mathrm{Na}, \mathrm{Mg}, \mathrm{Ca}, \mathrm{V}$, $\mathrm{Mn}, \mathrm{Fe}, \mathrm{Zn}, \mathrm{Al}, \mathrm{Cr}, \mathrm{Ni}, \mathrm{As}, \mathrm{Sr}, \mathrm{Ag}$, $\mathrm{Co}, \mathrm{Cu}$ for $A$. essettei; $\mathrm{Na}, \mathrm{Mg}, \mathrm{Ca}$, $\mathrm{V}, \mathrm{Mn}, \mathrm{Fe}, \mathrm{Zn}, \mathrm{Se}, \mathrm{Cr}, \mathrm{Ni}, \mathrm{As}, \mathrm{Sr}, \mathrm{Cd}$, $\mathrm{Cu}, \mathrm{Pb}$ for $A$. tabescens; $\mathrm{Na}, \mathrm{Mg}, \mathrm{Ca}$, $\mathrm{V}$, Se, Cr, Co for C. cornucopioides; $\mathrm{Se}$, As, Sr for $H$. fasciculare; $\mathrm{V}$, Se, $\mathrm{Cr}$, As, Sr, for L. nuda; Na, V, As, Sr for L. leucothites, $\mathrm{Na}, \mathrm{Mg}, \mathrm{Ca}, \mathrm{V}$, $\mathrm{Mn}, \mathrm{Se}, \mathrm{Al}, \mathrm{Ni}, \mathrm{As}, \mathrm{Sr}, \mathrm{Cd}$, Co for $O$. olearius; $\mathrm{Na}, \mathrm{Ca}, \mathrm{V}, \mathrm{Fe}, \mathrm{Se}, \mathrm{Al}, \mathrm{Ni}$, As, $\mathrm{Sr}, \mathrm{Co}, \mathrm{Pb}$ for P. torulosus; V, $\mathrm{Al}, \mathrm{Cr}, \mathrm{Ni}, \mathrm{As}, \mathrm{Sr}, \mathrm{Cd}, \mathrm{Pb}$ for $R$. flava; $\mathrm{Na}, \mathrm{Mg}, \mathrm{V}, \mathrm{Se}, \mathrm{Al}, \mathrm{Cr}, \mathrm{Ni}, \mathrm{As}$, Sr, Co for R. foetens; $\mathrm{Na}, \mathrm{Mg}, \mathrm{Ca}, \mathrm{V}$, $\mathrm{Se}, \mathrm{Al}$, As, $\mathrm{Sr}$, Co for T. versicolor) (Table II). The goal of this study is to make a complete scientific report on the metal concentrations of all the studied mushroom species grown in Turkey. Table II lists all of the metals previously studied and those studied in the present report.

\section{EXPERIMENTAL}

\section{Instrumentation}

The metals analyses were performed using an Agilent 7700x inductively coupled mass spectrometer (Agilent Technologies, Inc., U.S.). The instrumentation and the operating parameters are listed in Table III. 
TABLE I

Collection Localities and Dates, Family, and Edibility of the Studied Mushroom Species

\begin{tabular}{|c|c|c|c|c|c|}
\hline No. & Mushroom & Collection Localities and Dates & Family & Edibilty & Biological Activity \\
\hline 1 & Agaricus bisporus & Uşak, Banaz, December 2007 & Agaricaceae & Edible & {$[1,6,7,8,14,16,20,21]$} \\
\hline 2 & Agaricus bitorquis & Uşak, Banaz, December 2007 & Agaricaceae & Edible & {$[6]$} \\
\hline 4 & Armillaria tabescens & Uşak, Banaz, September 2009 & Marasmiaceae & Poisonus & {$[11,18]$} \\
\hline 5 & Craterellus cornucopioides & Uşak, Banaz, November 2009 & Cantharellaceae & Edible & {$[7,16,23,24]$} \\
\hline 6 & Hebeloma eburneum & Uşak, Banaz, November 2009 & Bolbitiaceae & Not edible & - \\
\hline 8 & Hypboloma fasciculare & Uşak, Banaz, November 2009 & Strophariaceae & Poisonus & {$[8,19]$} \\
\hline 91 & Lepista nuda & Uşak, Banaz, December 2008 & Tricholomataceae & Edible & {$[8,17,22,24]$} \\
\hline 101 & Leucoagaricus leucothites & Uşak, Banaz, September 2008 & Agaricaceae & Edible & [9] \\
\hline 111 & Melanoleuca graminicola & Uşak, Banaz, November 2008 & Tricholomataceae & Not edible & - \\
\hline 12 & Omphalotus olearius & Uşak-Banaz, November 2008 & Omphalotaceae & Poisonus & {$[25]$} \\
\hline 161 & Trametes versicolor & Uşak, Banaz, December 2008 & Polyporaceae & Not edible & {$[12,13,27,28]$} \\
\hline
\end{tabular}

TABLE II

The Studied Metals Versus the Studied Mushroom Species in the Literature ${ }^{\text {a }}$

\begin{tabular}{|c|c|c|c|c|c|c|c|c|c|c|c|c|c|c|c|c|}
\hline \multicolumn{17}{|c|}{ Mushroom species } \\
\hline$\frac{\infty}{\frac{\pi}{\pi}}$ & 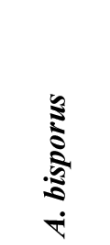 & 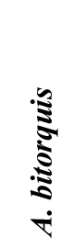 & 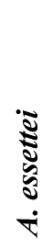 & 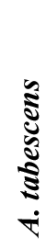 & 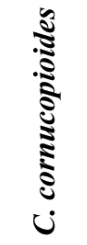 & 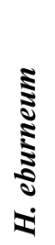 & 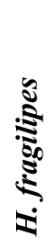 & 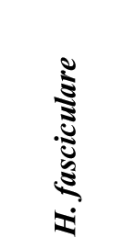 & 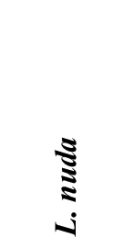 & 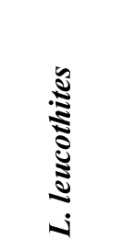 & 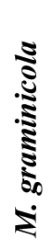 & 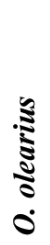 & 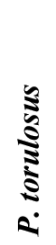 & 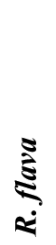 & 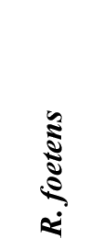 & 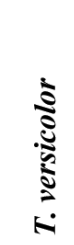 \\
\hline \multicolumn{17}{|c|}{ The minerals } \\
\hline $\mathbf{N a}$ & [31] & - & - & - & - & - & - & {$[40,41]$} & [43] & - & - & - & - & [48] & - & - \\
\hline Mg & {$[30,31]$} & {$[30,35]$} & - & - & - & & - & {$[40,41]$} & {$[30,43,44]$} & {$[30,45]$} & - & - & [47] & [48] & - & - \\
\hline Ca & {$[30,31]$} & {$[30,35]$} & - & - & - & - & - & {$[40,41]$} & {$[30,43,44]$} & {$[3,30,45]$} & - & - & - & - & [3] & - \\
\hline $\mathbf{V}$ & - & - & - & - & - & - & - & [41] & - & - & - & - & - & [48] & - & - \\
\hline Mn & [30-34] & [30] & - & - & {$[38,39]$} & - & - & {$[34,39,40,42]$} & {$[30,39,43,44]$} & {$[3,30,45,46]$} & - & - & - & [48] & {$[3,34,42]$} & [49] \\
\hline Fe & [30-33] & {$[30,35]$} & - & - & {$[38,39]$} & - & & [39-41] & {$[30,39,43,44]$} & {$[3,30,45,46]$} & - & & - & [48] & [3] & - \\
\hline Zn & {$[30,32-34]$} & [30] & - & - & {$[38,39]$} & & - & {$[34,39-42]$} & {$[30,39,43,44]$} & {$[3,30,45,46]$} & - & - & [47] & {$[48]$} & {$[3,34,42]$} & {$[\mathbf{5 0}]$} \\
\hline $\mathrm{Se}$ & [31] & [36] & {$[36]$} & - & - & - & - & - & - & [3] & - & - & - & [48] & [3] & - \\
\hline \multicolumn{17}{|c|}{ The heavy metals and others } \\
\hline $\mathbf{A l}$ & - & [35] & - & [37] & [39] & - & - & {$[40,41]$} & {$[37,39]$} & {$[30,45,46]$} & - & - & - & - & - & - \\
\hline $\mathrm{Cr}$ & [33] & - & - & - & - & & - & [41] & - & [45] & - & - & & & - & [49] \\
\hline $\mathbf{N i}$ & {$[30,32,33]$} & [30] & - & - & [38] & & - & [41] & [30] & {$[30,45]$} & - & - & [47] & & - & [49] \\
\hline As & - & - & - & - & [38] & - & - & - & - & - & - & - & - & - & - & - \\
\hline $\mathrm{Sr}$ & - & - & - & - & [38] & - & - & - & - & - & - & - & - & - & - & - \\
\hline Co & {$[32,33]$} & - & - & - & - & - & - & [41] & {$[37,43]$} & {$[37,45]$} & - & - & - & [48] & - & - \\
\hline $\mathbf{C u}$ & [31-33] & [30] & - & - & {$[38,39]$} & - & - & {$[34,40-42]$} & {$[30,39,43,44]$} & {$[30,45]$} & - & [3] & [47] & [48] & {$[34,42]$} & {$[49,50]$} \\
\hline $\mathbf{P b}$ & [30-33] & {$[30,36]$} & [36] & - & {$[38,39]$} & - & - & {$[34,40,41]$} & {$[30,39]$} & {$[30,45,46]$} & - & - & - & - & {$[34,42]$} & {$[49,50]$} \\
\hline
\end{tabular}




\section{Reagents, Standards, and Samples}

Nitric acid $\left(\mathrm{HNO}_{3}, 65 \%\right)$ and hydrogen peroxide $\left(\mathrm{H}_{2} \mathrm{O}_{2}, 30 \%\right)$ were obtained from E. Merck (Darmstadt, Germany). All other chemicals and solvents were of analytical reagent grade. For calibration plots, the standard solutions were prepared by diluting the stock solutions with ultrapure water containing $0.2 \% \mathrm{HNO}_{3}$ and $0.3 \% \mathrm{HCl}$. In order to check the accuracy of the method, the certified reference materials (CRM) NIST-CRM-1203 Drinking Water, NIST-CRM-1570a Spinach Leaves, and NIST-CRM1573a Tomato Leaves were used (National Institute of Standards and Technology, Gaithersburg, MD, USA). Agilent No. 5188-6525 was used as the internal standard for scandium, germanium, indium, and bismuth. The names of the species and their family classification, collection dates and localities, as well as the edibility of the 16 mushroom species, are listed in Table I. The voucher specimens of these species have been deposited in the Fungarium at the Department of Biology, Mugla Sitkı Koçman University, Mugla, Turkey.

\section{Sample Preparation}

The collected samples were cleaned, sliced, and dried in an oven (Nüve, Istanbul, Turkey) at $105{ }^{\circ} \mathrm{C}$ for 24 hours. The dried samples were homogenized using a homogenizer (IKA, Staufen, Germany), sifted using a 10-mesh sieve, and (particle size of $1600 \mu \mathrm{m}$, average) stored in pre-cleaned polyethylene bottles for analysis. All aqueous solutions were prepared by using deionized water (18.2 $\left.\mathrm{M} \Omega . \mathrm{cm}^{-1}\right)$ from a Milli-Q ${ }^{\circledR}$ system (Human Power I Plus, Korea). All plastic and glassware were cleaned by soaking in $10 \%$ nitric acid solution overnight and rinsing with deionized water. For digestion, a CEM Mars 5 microwave closed sys-

TABLE III

ICP-MS Instrumental Operating Conditions

\begin{tabular}{ll} 
Instrument & Agilent \\
RF power & $1600 \mathrm{~W}$ \\
RF match & $2.10 \mathrm{~V}$ \\
Sampling depth & $10.0 \mathrm{~nm}$ \\
Nebulizer gas & $0.57 \mathrm{~L} / \mathrm{min}$ \\
S/C temperature & $2{ }^{\circ} \mathrm{C}$ \\
Nebulizer type & MicroMist \\
Spray chamber & Scott-type double-pass \\
Ar flow rate & Plasma: $15 \mathrm{~L} / \mathrm{min}$ \\
& Auxiliary: $0.9 \mathrm{~L} / \mathrm{min}$ \\
Solution uptake rate & $1.8 \mathrm{~mL} / \mathrm{min}$ \\
VacuumInterface & 4 torr, quadrupole: $2{ }^{105} \mathrm{torr}$ \\
Data acquisition & Peak hopping \\
& Replicate time $200 \mathrm{~ms}$ \\
& Dwell time $200 \mathrm{~ms}$ \\
& Sweeps/reading 3 \\
& Readings/replicate 3 \\
& Number of replicates 3 \\
Analytical masses & ${ }^{23} \mathrm{Na},{ }^{24} \mathrm{Mg},{ }^{43} \mathrm{Ca},{ }^{51} \mathrm{~V},{ }^{55} \mathrm{Mn},{ }^{56} \mathrm{Fe},{ }^{66} \mathrm{Zn},{ }^{69} \mathrm{Ga},{ }^{82} \mathrm{Se}$, \\
& ${ }^{27} \mathrm{Al},{ }^{52} \mathrm{Cr},{ }^{60} \mathrm{Ni},{ }^{75} \mathrm{As},{ }^{88} \mathrm{Sr},{ }^{206} \mathrm{~Pb},{ }^{59} \mathrm{Co},{ }^{63} \mathrm{Cu}$ \\
\hline
\end{tabular}

\section{Atomic Apectroscopy 1 Vol. 39(1), Jan./Feb. 2018}

tem (CEM, Matthews, NC, USA) was used. Samples of $0.25 \mathrm{~g}$ were digested with $9 \mathrm{~mL}$ of $\mathrm{HNO}_{3}(65 \%)$ and $1 \mathrm{~mL}$ of $\mathrm{H}_{2} \mathrm{O}_{2}(30 \%)$ in the microwave for 23 minutes, then diluted to $25 \mathrm{~mL}$ with deionized water. A blank digest was carried out in the same way. The microwave digestion temperature was set to $180{ }^{\circ} \mathrm{C}$ for 5 minutes and kept constant for 2 minutes. This digestion heating program was used for all samples.

\section{ICP-MS Analysis Procedure}

For the elemental analysis, an Agilent 7700x ICP-MS was used. All metal concentrations were determined on a dry weight basis. The procedures from sampling to analysis were also applied to blanks to evaluate any metal contamination during the analytical procedure. The limit of detection (LOD) is defined as the concentration corresponding to three times the standard deviation of 10 blanks. The ICP-MS detection limits $(\mu \mathrm{g} / \mathrm{L})$ of the elements were found to be 0.0098 for $\mathrm{Pb}, 0.1151$ for $\mathrm{Zn}$, 0.0069 for $\mathrm{Fe}, 0.0108$ for $\mathrm{Mn}$, 0.0029 for $\mathrm{Cu}, 0.0162$ for $\mathrm{Cr}$, 0.0311 for $\mathrm{Ni}, 0.0006$ for $\mathrm{Co}$, 0.7630 for $\mathrm{Na}, 0.1468$ for $\mathrm{Mg}$, 0.7821 for $\mathrm{Al}, 0.7393$ for $\mathrm{Ca}, 0.0103$ for $\mathrm{V}, 0.0245$ for As, 0.0219 for Se, and 0.0213 for Sr. The ICP-MS operating conditions are listed in Table III. The standard reference material (SRM) NIST-CRM-1203 Drinking Water, and NIST-CRM-1570a Spinach Leaves, and NIST-CRM1573a Tomato Leaves were used to check the accuracy of the analytical method. Agilent No. 5188-6525 was used as the internal standard. The results obtained are listed in Table IV. The relative standard deviation (RSD) was below 8\% (51).

In ICP-MS, most elements have multiple isotopes which are corrected mathematically for both isobaric and polyatomic interferences. By considering the natural abundance of different isotopes and 
TABLE IV

Certified and Experimental Values of Studied Metals in NIST-CRM 1203 Drinking Water, NIST-CRM 1570a Spinach Leaves, and NIST-CRM 1573a Tomato Leaves (mg/kg) ${ }^{a}$

\begin{tabular}{|c|c|c|c|c|c|c|c|c|c|}
\hline \multirow[t]{2}{*}{ Metal } & \multicolumn{3}{|c|}{$\begin{array}{l}\text { NIST-CRM } 1203 \\
\text { king Water }(\mathrm{mg} / \mathrm{kg})\end{array}$} & \multicolumn{2}{|c|}{$\begin{array}{c}\text { NIST-CRM 1570a } \\
\text { Spinach Leaves (mg/kg) }\end{array}$} & \multicolumn{4}{|c|}{$\begin{array}{l}\text { NIST-CRM } 1573 \mathrm{a} \\
\text { Tomato Leaves }(\mathrm{mg} / \mathrm{kg})\end{array}$} \\
\hline & $\begin{array}{l}\text { Certified } \\
\text { Value } \\
\text { (mg/kg) }\end{array}$ & $\begin{array}{l}\text { Experimental } \\
\text { Value + S.D. } \\
(\mathrm{mg} / \mathrm{kg})^{\mathrm{b}}\end{array}$ & $\begin{array}{l}\text { Recovery } \\
\text { Value } \\
(\%)\end{array}$ & $\begin{array}{l}\text { Certified } \\
\text { Value } \\
\text { (mg/kg) }\end{array}$ & $\begin{array}{l}\text { Experimental } \\
\text { Value + S.D. } \\
(\mathrm{mg} / \mathrm{kg})^{\mathrm{b}}\end{array}$ & $\begin{array}{c}\text { Recovery } \\
\text { Value } \\
(\%)\end{array}$ & $\begin{array}{l}\text { Certified } \\
\text { Value } \\
(\mathrm{mg} / \mathrm{kg})\end{array}$ & $\begin{array}{l}\text { Value + S.D. } \\
(\mathrm{mg} / \mathrm{kg})^{\mathrm{b}}\end{array}$ & $\begin{array}{c}\text { Recovery } \\
\text { Value } \\
(\%)\end{array}$ \\
\hline $\mathrm{Al}$ & $250.5 \pm 1.3$ & $251.6 \pm 2.01$ & 100.44 & $310 \pm 14$ & $285 \pm 15$ & 91.2 & $598 \pm 12$ & $596 \pm 2$ & 99.7 \\
\hline As & $15.00 \pm 0.08$ & $14.48 \pm 0.35$ & 96.53 & $0.068 \pm 0.012$ & $0.066 \pm 0.014$ & 95.1 & $0.112 \pm 0.004$ & $0.111 \pm 0.008$ & 99.1 \\
\hline $\mathrm{Ca}$ & $99.78 \pm 0.50$ & $100.42 \pm 0.95$ & 100.64 & - & - & & & - & - \\
\hline $\mathrm{Co}$ & $5.00 \pm 0.03$ & $5.22 \pm 0.18$ & 104.40 & $0.39 \pm 0.05$ & $0.38 \pm 0.07$ & 94.8 & $0.57 \pm 0.02$ & $0.55 \pm 0.08$ & 96.5 \\
\hline $\mathrm{Cr}$ & $50.09 \pm 0.25$ & $49.92 \pm 0.56$ & 99.66 & - & - & - & $1.99 \pm 0.06$ & $2.02 \pm 0.12$ & 101.5 \\
\hline $\mathrm{Cu}$ & $2000 \pm 10$ & $202.9 \pm 0.12$ & 101.45 & $12.2 \pm 0.7$ & $12.0 \pm 0.8$ & 97.3 & $4.70 \pm 0.14$ & $4.71 \pm 0.05$ & 100.2 \\
\hline $\mathrm{Fe}$ & $200.3 \pm 1.0$ & $199.89 \pm 2.05$ & 99.94 & - & - & - & $368 \pm 7$ & $373 \pm 2$ & 101.4 \\
\hline $\mathrm{Mg}$ & $99.77 \pm 0.50$ & $100.68 \pm 1.02$ & 100.23 & - & - & - & - & - & - \\
\hline Mn & $50.17 \pm 0.25$ & $50.02 \pm 0.75$ & 99.67 & $76 \pm 1.4$ & $75 \pm 2.6$ & 98.6 & $246 \pm 8$ & $243 \pm 3$ & 99.8 \\
\hline $\mathrm{Na}$ & $49.68 \pm 0.25$ & $50.01 \pm 0.78$ & 100.66 & - & - & - & $136 \pm 4$ & $138 \pm 2$ & 101.5 \\
\hline $\mathrm{Ni}$ & $50.16 \pm 0.25$ & $4.93 \pm 0.61$ & 97.05 & $2.14 \pm 0.07$ & $2.22 \pm 0.15$ & 103.6 & $1.59 \pm 0.07$ & $1.56 \pm 0.03$ & 98.2 \\
\hline $\mathrm{Pb}$ & $24.99 \pm 0.12$ & $2.44 \pm 0.68$ & 97.99 & - & - & - & $0.075 \pm 0.025$ & $0.079 \pm 0.012$ & 101.4 \\
\hline $\mathrm{Se}$ & $10.00 \pm 0.05$ & $10.08 \pm 0.24$ & 106.93 & $0.116 \pm 0.009$ & $0.120 \pm 0.010$ & 103.7 & $0.054 \pm 0.003$ & $0.055 \pm 0.007$ & 101.9 \\
\hline $\mathrm{Sr}$ & - & - & - & $55.5 \pm 0.6$ & $54.9 \pm 1.8$ & 101.8 & - & - & - \\
\hline V & - & - & - & $0.57 \pm 0.02$ & $0.56 \pm 0.04$ & 98.4 & $0.835 \pm 0.010$ & $0.839 \pm 0.009$ & 100.5 \\
\hline $\mathrm{Zn}$ & $1000 \pm 5$ & $1003.1 \pm 7.8$ & 102.59 & $82 \pm 3.9$ & $80 \pm 5$ & 97.5 & $30.9 \pm 0.7$ & $31.5 \pm 1.0$ & 101.5 \\
\hline
\end{tabular}

${ }^{a}$ Ten times dilution of Certified NIST-SRM 1203 Drinking Water, NIST-CRM 1570a Spinach Leaves, and NIST-CRM 1573a Tomato Leaves $(\mathrm{mg} / \mathrm{kg})$.

${ }^{\mathrm{b}}$ Average of triplicate measurements of certified material $(\mathrm{p}<0.05)$.

TABLE V

Mineral Content (mg/kg Mushroom of Dry Weight) of Mushroom Species ${ }^{\text {a }}$

\begin{tabular}{lcccccccc}
\hline No & $\mathrm{Na}$ & $\mathrm{Mg}$ & $\mathrm{Ca}$ & $\mathrm{V}$ & $\mathrm{Mn}$ & $\mathrm{Fe}$ & $\mathrm{Zn}$ & $\mathrm{Se}$ \\
\hline $1^{\mathrm{e}}$ & $883 \pm 7$ & $323 \pm 3$ & $52.2 \pm 2$ & $0.36 \pm 0.02$ & $3.60 \pm 0.12$ & $17.3 \pm 1$ & $9.71 \pm 0.4$ & $0.03 \pm 0.01$ \\
$2^{\mathrm{e}}$ & $487 \pm 5$ & $297 \pm 3$ & $63.2 \pm 2$ & $0.72 \pm 0.05$ & $10.2 \pm 0.51$ & $114 \pm 3$ & $13.4 \pm 0.5$ & $0.21 \pm 0.02$ \\
$3^{\mathrm{e}}$ & $235 \pm 3$ & $190 \pm 3$ & $19.1 \pm 1$ & $0.58 \pm 0.04$ & $4.92 \pm 0.14$ & $66.1 \pm 2$ & $10.1 \pm 0.6$ & $0.16 \pm 0.01$ \\
$4^{\mathrm{p}}$ & $1717 \pm 10$ & $795 \pm 5$ & $69.2 \pm 2$ & $0.91 \pm 0.03$ & $18.3 \pm 0.22$ & $218 \pm 6$ & $15.9 \pm 1.1$ & $0.19 \pm 0.01$ \\
$5^{\mathrm{e}}$ & $619 \pm 6$ & $498 \pm 4$ & $41.4 \pm 1$ & $0.19 \pm 0.01$ & $76.4 \pm 2.84$ & $77.1 \pm 3$ & $16.7 \pm 0.8$ & $0.04 \pm 0.01$ \\
$6^{\text {ne }}$ & $562 \pm 5$ & $666 \pm 5$ & $46.2 \pm 2$ & $0.25 \pm 0.01$ & $8.21 \pm 0.40$ & $231 \pm 3$ & $21.7 \pm 0.9$ & $0.08 \pm 0.02$ \\
$7^{\text {ne }}$ & $228 \pm 3$ & $735 \pm 5$ & $75.1 \pm 2$ & $0.76 \pm 0.03$ & $18.7 \pm 0.82$ & $172 \pm 2$ & $43.3 \pm 2.4$ & $0.56 \pm 0.01$ \\
$8^{\mathrm{p}}$ & $121 \pm 2$ & $122 \pm 2$ & $15.1 \pm 1$ & $1.04 \pm 0.07$ & $38.3 \pm 1.11$ & $198 \pm 3$ & $3.91 \pm 0.1$ & $0.29 \pm 0.01$ \\
$9^{\mathrm{e}}$ & $401 \pm 5$ & $600 \pm 5$ & $113 \pm 4$ & $0.29 \pm 0.02$ & $13.6 \pm 0.83$ & $174 \pm 4$ & $21.2 \pm 0.8$ & $0.16 \pm 0.01$ \\
$10^{\mathrm{e}}$ & $722 \pm 5$ & $1050 \pm 8$ & $142 \pm 5$ & $0.56 \pm 0.03$ & $8.61 \pm 0.31$ & $115 \pm 1$ & $52.4 \pm 2.5$ & $0.14 \pm 0.01$ \\
$11^{\text {ne }}$ & $426 \pm 4$ & $788 \pm 6$ & $105 \pm 2$ & $0.62 \pm 0.02$ & $44.4 \pm 1.52$ & $395 \pm 3$ & $35.9 \pm 1.2$ & $0.13 \pm 0.01$ \\
$12^{\mathrm{p}}$ & $274 \pm 3$ & $205 \pm 3$ & $18.1 \pm 1$ & $0.12 \pm 0.01$ & $5.05 \pm 0.14$ & $84.3 \pm 2$ & $3.4 \pm 0.1$ & $0.03 \pm 0.01$ \\
$13^{\mathrm{ne}}$ & $46 \pm 1$ & $301 \pm 3$ & $316 \pm 3$ & $0.18 \pm 0.01$ & $4.32 \pm 0.13$ & $41.2 \pm 1$ & $7.71 \pm 0.2$ & $0.04 \pm 0.01$ \\
$14^{\mathrm{e}}$ & $307 \pm 3$ & $804 \pm 6$ & $19.1 \pm 1$ & $0.21 \pm 0.01$ & $22.5 \pm 1.43$ & $90.1 \pm 2$ & $14.5 \pm 1.0$ & $0.19 \pm 0.01$ \\
$15^{\text {ne }}$ & $731 \pm 5$ & $765 \pm 5$ & $57.1 \pm 2$ & $0.21 \pm 0.01$ & $8.92 \pm 0.53$ & $198 \pm 3$ & $13.7 \pm 0.3$ & $0.21 \pm 0.01$ \\
$16^{\text {ne }}$ & $177 \pm 2$ & $1121 \pm 7$ & $109 \pm 3$ & $0.09 \pm 0.01$ & $9.81 \pm 0.62$ & $96.1 \pm 1$ & $70.7 \pm 2.6$ & $0.06 \pm 0.01$ \\
\hline
\end{tabular}

${ }^{a}$ Values expressed are means \pm S.E.M. of three parallel measurements $(\mathrm{p}<0.05)$.

e Edible mushroom species; ${ }^{\mathrm{P}}$ Poisonous mushroom species; ${ }^{\text {ne }}$ not edible mushroom species; ${ }^{\mathrm{NA}}$ Not Available. 
measuring the intensity of a noninterfered isotope, the extent of the interference and the contribution to yield is then subtracted and the concentration calculated. Moreover, the nebulizer gas of Ar may combine with other atoms and leads to some interferences. For example, $\mathrm{ArO}, \mathrm{ArC}$, and $\mathrm{ArCl}$ may occur in the plasma, and act on behalf of Fe, $\mathrm{Cr}$, and As, respectively. The developed ORS (Octopole Reaction System) in ICP-MS separates these polyatomic interferences by using helium as a collision gas. Thus, any possible interferences are prevented by using the ORS.

\section{RESULTS AND DISCUSSION}

The concentration of 8 minerals ( $\mathrm{Na}, \mathrm{Mg}, \mathrm{Ca}, \mathrm{V}, \mathrm{Mn}, \mathrm{Fe}, \mathrm{Zn}$, and $\mathrm{Se}$ ) and 8 heavy metals (Al, Cr, Ni, As, $\mathrm{Sr}, \mathrm{Pb}, \mathrm{Co}$, and $\mathrm{Cu}$ ) was studied in mushroom species. Their concentrations in the various mushroom species are listed in the Tables $\mathrm{V}$ and VI as $\mathrm{mg} / \mathrm{kg}$ dry weight, respectively.

\section{Mineral Element Concentrations}

Sodium (Na) is an essential macro element for humans and animals and has an important physiological effect on different organs and the cellular mechanisms, such as the $\mathrm{K} / \mathrm{Na}$ pump of cell membranes (52). The Na concentrations ranged between $46 \pm 1$ to $1717 \pm 10 \mathrm{mg} / \mathrm{kg}$ in the mushroom species. The highest and lowest $\mathrm{Na}$ concentrations were obtained in A. tabescens and $P$. torulosus, respectively (Table V). The recommended minimum daily intake for $\mathrm{Na}$ is about $1500 \mathrm{mg}$ and the maximum requirement is 2400 mg per day (53).

Magnesium (Mg) is a major mineral for the human body and the daily dietary intake is between 168$319 \mathrm{mg}$, with an estimated average requirement for males of 330-350

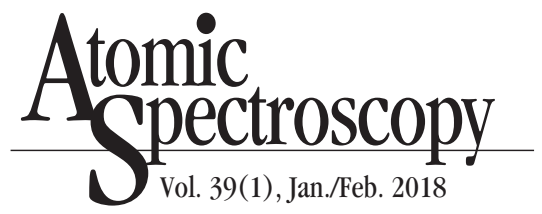

$\mathrm{mg} /$ day, for females of 255-265 $\mathrm{mg} /$ day (54). Mg is important for the formation of the skeletal structure with regard to bone quality. Dietary deficiency of $\mathrm{Mg}$ has been implicated as a risk factor for osteoporosis (55). The Mg concentration of the mushroom species ranged from $122 \pm 2$ to $1121 \pm 7 \mathrm{mg} / \mathrm{kg}$. The highest and lowest of $\mathrm{Mg}$ levels were found in T. versicolor and $H$. fasciculare, respectively.

Calcium (Ca) is an element whose behavior seems to be very interesting because there are quite substantial differences between both the phylogenetic position and lifestyle (41). The Ca content in the mushroom samples was between $15 \pm 1$ to $316 \pm 3 \mathrm{mg} / \mathrm{kg}$. The lowest and highest Ca values were observed in $H$. fasciculare and $P$. torulosus, respectively. The recommended daily dietary intake of $\mathrm{Ca}$ is between 466-880 $\mathrm{mg}$, and the adequate intake for adults is $1-1.2 \mathrm{~g}(54)$.

TABLE VI

Heavy Metal Content (mg/kg Mushroom of Dry Weight) of the Mushroom Species ${ }^{\text {a }}$

\begin{tabular}{lcccccccc}
\hline No & $\mathrm{Al}$ & $\mathrm{Cr}$ & $\mathrm{Ni}$ & $\mathrm{As}$ & $\mathrm{Sr}$ & $\mathrm{Co}$ & $\mathrm{Cu}$ & $\mathrm{Pb}$ \\
\hline $1^{\mathrm{e}}$ & $440 \pm 4$ & $0.14 \pm 0.01$ & $0.19 \pm 0.01$ & $0.43 \pm 0.02$ & $5.66 \pm 0.12$ & $0.02 \pm 0.00$ & $9.89 \pm 0.65$ & $0.43 \pm 0.03$ \\
$2^{\mathrm{e}}$ & $491 \pm 4$ & $0.30 \pm 0.02$ & $0.68 \pm 0.02$ & $0.91 \pm 0.05$ & $9.71 \pm 1.05$ & $0.24 \pm 0.01$ & $5.03 \pm 0.24$ & $1.34 \pm 0.05$ \\
$3^{\mathrm{e}}$ & $129 \pm 2$ & $0.34 \pm 0.02$ & $0.36 \pm 0.02$ & $0.26 \pm 0.01$ & $6.87 \pm 0.36$ & $0.23 \pm 0.01$ & $7.37 \pm 0.36$ & $0.31 \pm 0.02$ \\
$4^{\mathrm{p}}$ & $144 \pm 3$ & $0.35 \pm 0.01$ & $0.57 \pm 0.04$ & $2.65 \pm 0.12$ & $13.4 \pm 1.02$ & $0.30 \pm 0.02$ & $2.32 \pm 0.06$ & $1.74 \pm 0.06$ \\
$5^{\mathrm{e}}$ & $388 \pm 2$ & $0.15 \pm 0.01$ & $0.18 \pm 0.01$ & $0.19 \pm 0.01$ & $7.43 \pm 0.47$ & $0.06 \pm 0.00$ & $0.58 \pm 0.04$ & $0.07 \pm 0.00$ \\
$6^{\mathrm{ne}}$ & $398 \pm 3$ & $0.56 \pm 0.03$ & $3.40 \pm 0.09$ & $0.87 \pm 0.45$ & $4.55 \pm 0.24$ & $0.37 \pm 0.02$ & $0.57 \pm 0.02$ & $0.11 \pm 0.00$ \\
$7^{\text {ne }}$ & $122 \pm 2$ & $0.33 \pm 0.02$ & $0.58 \pm 0.03$ & $4.43 \pm 0.25$ & $10.0 \pm 0.28$ & $0.38 \pm 0.03$ & $1.87 \pm 0.08$ & $0.18 \pm 0.01$ \\
$8^{\mathrm{p}}$ & $360 \pm 2$ & $0.17 \pm 0.01$ & $0.39 \pm 0.01$ & $1.96 \pm 0.08$ & $2.41 \pm 0.09$ & $0.97 \pm 0.05$ & $1.01 \pm 0.08$ & $0.29 \pm 0.02$ \\
$9^{\mathrm{e}}$ & $432 \pm 4$ & $0.20 \pm 0.01$ & $0.55 \pm 0.03$ & $0.29 \pm 0.01$ & $14.9 \pm 1.19$ & $0.13 \pm 0.01$ & $0.21 \pm 0.01$ & $0.58 \pm 0.03$ \\
$10^{\mathrm{e}}$ & $575 \pm 5$ & $0.61 \pm 0.04$ & $0.69 \pm 0.04$ & $0.46 \pm 0.03$ & $4.53 \pm 0.14$ & $0.29 \pm 0.02$ & $1.45 \pm 0.05$ & $1.91 \pm 0.05$ \\
$11^{\mathrm{ne}}$ & $108 \pm 2$ & $0.51 \pm 0.02$ & $0.57 \pm 0.04$ & $1.20 \pm 0.05$ & $10.1 \pm 0.79$ & $0.43 \pm 0.03$ & $0.72 \pm 0.03$ & $3.33 \pm 0.06$ \\
$12^{\mathrm{p}}$ & $145 \pm 3$ & $0.19 \pm 0.01$ & $0.43 \pm 0.01$ & $0.38 \pm 0.02$ & $7.97 \pm 0.62$ & $0.05 \pm 0.00$ & $0.20 \pm 0.01$ & $0.20 \pm 0.01$ \\
$13^{\mathrm{ne}}$ & $143 \pm 1$ & $0.08 \pm 0.00$ & $0.69 \pm 0.03$ & $0.29 \pm 0.02$ & $9.07 \pm 0.32$ & $0.10 \pm 0.01$ & $1.27 \pm 0.08$ & $0.05 \pm 0.00$ \\
$14^{\mathrm{e}}$ & $352 \pm 2$ & $0.25 \pm 0.01$ & $1.61 \pm 0.08$ & $0.69 \pm 0.05$ & $3.45 \pm 0.11$ & $3.44 \pm 0.18$ & $8.03 \pm 0.56$ & $1.56 \pm 0.10$ \\
$15^{\mathrm{ne}}$ & $451 \pm 4$ & $0.49 \pm 0.03$ & $3.95 \pm 0.09$ & $0.29 \pm 0.01$ & $4.92 \pm 0.35$ & $0.53 \pm 0.04$ & $0.24 \pm 0.01$ & $0.26 \pm 0.02$ \\
$16^{\mathrm{ne}}$ & $169 \pm 5$ & $0.28 \pm 0.01$ & $0.96 \pm 0.05$ & $0.24 \pm 0.01$ & $6.78 \pm 0.14$ & $0.14 \pm 0.02$ & $0.17 \pm 0.01$ & $0.27 \pm 0.01$ \\
$\mathrm{WHO}^{\mathrm{n} H \mathrm{HO}}$ & & & & & & & &
\end{tabular}

\footnotetext{
${ }^{\mathrm{a}}$ Values expressed are means \pm S.E.M. of three parallel measurements $(\mathrm{p}<0.05) .{ }^{\mathrm{b}}$ citied reference in the text; ${ }^{\mathrm{c}} \mathrm{mg} / \mathrm{kg} / \mathrm{body} \mathrm{weight}$;
}

${ }^{\mathrm{e}}$ Edible mushroom species; ${ }^{\mathrm{P}}$ Poisonous mushroom species; ${ }^{\text {ne }}$ not edible mushroom species; ${ }^{\mathrm{NA}}$ Not Available. 
Vanadium (V) is present at very low concentrations in virtually all cells in plants and animals. Numerous studies have demonstrated that compounds of the trace element $\mathrm{V}$ exert antidiabetic effects in vitro and in vivo (56). However, the toxicity associated with $\mathrm{V}$ limits its role as a therapeutic agent for diabetic treatment (57). The V concentrations in the studied mushroom species ranged from $0.09 \pm 0.01$ to $1.04 \pm 0.07 \mathrm{mg} / \mathrm{kg}$. The recommended $\mathrm{V}$ concentration in foods is between 19 to $50 \mu \mathrm{g} / \mathrm{day}$ (58).

Manganese (Mn) is an essential component of many enzymes and also activates numerous enzymes (32). The minimum and maximum Mn levels found were 3.60 \pm 0.12 $\mathrm{mg} / \mathrm{kg}$ and $76.40 \pm 2.84 \mathrm{mg} / \mathrm{kg}$ for $A$. bisporus and C. cornucopioides, respectively. The mean concentration range of $\mathrm{Mn}$ in vegetables is between $0.42-6.64(\mathrm{mg} / \mathrm{kg})$. Several investigations of adult diets exhibited that the average daily consumption of $\mathrm{Mn}$ is between 2.0 to $8.8 \mathrm{mg}(59)$.

Iron (Fe) is essential for nearly all living organisms. It is known that adequate Fe in a diet is very important for decreasing the incidence of anemia. Iron deficiency occurs when the demand for iron is high, e.g., for growth, due to high menstrual loss and pregnancy, and the intake is quantitatively inadequate or contains elements that render the iron unavailable for absorption (60). The Fe concentrations in this study ranged from $173 \pm 1$ and $395 \pm 3 \mathrm{mg} / \mathrm{kg}$ and was highest in $M$. graminicola and lowest in $A$. bisporus. According to the National Research Council (61), the recommended daily intake of iron in foods ranges from 10 to $14 \mathrm{mg}$.

Zinc ( $\mathrm{Zn})$ is an essential nutrient that plays an important role in the biological systems (62). It is a central metal of various enzymes which are synthase or degrade the carbohydrates, lipids, proteins, and nucleic acids in the biological fluids. Another role of $\mathrm{Zn}$ is maintenance of cell and organ integrity by stabilizing the molecular structure of cellular components. In addition, $\mathrm{Zn}$ plays a central role in the immune system (63). Some mushrooms are known as $\mathrm{Zn}$ accumulators, and the mushroom-to-underlying soil ratio for zinc ranges from 1 to $10 \mathrm{mg} / \mathrm{kg}$. The highest zinc level was found in L. leucotbites $(52.4 \pm 2.5 \mathrm{mg} / \mathrm{kg})$, and the lowest $\mathrm{Zn}$ content was found in $O$. olearius $(3.4 \pm 0.1 \mathrm{mg} / \mathrm{kg})$. The calculated daily dietary intake of $\mathrm{Zn}$ is $16 \mathrm{mg}$ for males and $12 \mathrm{mg}$ for females (64).

Selenium (Se) is an essential nutrient, and Se deficiency is associated with general impairment of the immune system and has a protective role in preventing carcinogenesis and other chronic diseases. There is evidence that Se also plays an antioxidant role (65). The minimum and maximum Se concentrations were $0.03 \pm 0.01 \mathrm{mg} / \mathrm{kg}$ in $A$. bisporus and $0.56 \pm 0.01 \mathrm{mg} / \mathrm{kg}$ in $H$. fragilipes, respectively. The daily recommendation of Se intake for adult females and males is 26 and $35 \mu \mathrm{g}$, respectively (66).

\section{Heavy Metals Concentrations}

The heavy metals concentrations of the mushroom species are listed in Table VI including the WHO recommended limits. Aluminum (Al) is not considered to be an essential element in humans. Exposure of $\mathrm{Al}$ has been implicated in a number of human pathologies including dementia, Parkinson's disease, and Alzheimer's disease. Aluminum is naturally present in large amounts in potatoes, spinach, and tea which are generally considered highly preferred foods (67). Al is not normally added to foods but can be a contaminamt in some processed foods during the production process (60). The Al content of the mushroom species ranges from $108 \pm 2 \mathrm{mg} / \mathrm{kg}$ in M. graminicola to $575 \pm 5 \mathrm{mg} / \mathrm{kg}$ in L. leucotbites. Daily dietary intake of $\mathrm{Al}$ for adults varies fromcountry to country. Al intake in Australia is 1.9-2.4, while in Europe it is $3.1-13$, and in the USA it is $7.1-8.2 \mathrm{mg} / \mathrm{day}$. Consumption of $5 \mathrm{~g} /$ day is considered to be high (67).

Chromium (Cr) is an essential mineral for humans and has been related to the carbohydrate, lipid, and protein metabolism. The recommended daily intake is 50-200 $\mu \mathrm{g}$ (60). The minimum and maximum contents of $\mathrm{Cr}$ found were $0.14 \pm 0.01 \mathrm{mg} / \mathrm{kg}$ in $A$. bisporus and $0.61 \pm 0.04 \mathrm{mg} / \mathrm{kg}$ in L. leucothites, respectively.

Trace amounts of nickel (Ni) may be beneficial as an activator of some enzyme systems, such as urease (68). The tolerable daily intake level of $\mathrm{Ni}$ is given as $1 \mathrm{mg}$ per $\mathrm{kg}$ of body weight per day (69). At upper limits, it is considered toxic. It accumulates in the lungs and may cause bronchial hemorrhage or collapse (60). The minimum and maximum contents of $\mathrm{Ni}$ in mushroom species were $0.18 \pm 0.01$ and $3.95 \pm 0.09 \mathrm{mg} / \mathrm{kg}$. The highest value was found in C. cornucopioides, whereas for $R$. foetens, it was the lowest value.

Arsenic (As) is generally found at low concentrations $(0-20 \mathrm{mg} / \mathrm{kg})$, with the exception of rice (150-25 $\mathrm{mg} / \mathrm{kg}$ ) and certain edible mushrooms (several milligrams per kilogram) in the terrestrial environment (70). The As content in this study ranged from $0.19 \pm 0.01$ and $4.43 \pm 0.25 \mathrm{mg} / \mathrm{kg}$ and was highest in $H$. fragilipes and lowest in $C$. cornucopioides. The promulgated daily limits by WHO for As is less than $4 \mathrm{mg} / \mathrm{kg}$ in foods for adults (71).

The highest $(14.9 \pm 1.19 \mathrm{mg} / \mathrm{kg})$ and the lowest $(2.41 \pm 0.09 \mathrm{mg} / \mathrm{kg})$ concentrations of strontium (Sr) were found in $L$. nuda and $H$. fasciculare, respectively. Exposure to 
high levels of Sr during infancy and childhood can affect bone growth and cause dental changes, while there is no evidence to suggest that ingestion of foods that naturally contain traces of strontium is harmful. Effects during adulthood are less well understood, but there is some evidence that strontium increases bone density. According to the U.S. Environmental Protection Agency (EPA), water with $\mathrm{Sr}$ levels higher than $4 \mathrm{mg} / \mathrm{L}$ cannot be used in the preparation of beverages and foods. This means that for an adult having a $130 \mu \mathrm{g} / \mathrm{kg}$ body weight, the amount of $4 \mathrm{mg} / \mathrm{L} \mathrm{Sr}$ is toxic.

Cobalt (Co) is an important trace element in nature and can be either essential or toxic for many biological systems, depending on its concentration range (68). For example, Co is essential for nitrogen fixation by symbiotic systems, blue-green algae, and free-living bacteria. In higher plants, Co is a necessary element for legumes (72). Cobalt exposes toxicity over oxidant-based and free radical-based processes as hypothesis. It also affects genes sensitive to oxidant status. This leads to apoptosis. Neuromuscular transmissions can be affected by cobalt (72). The average content of Co was found to be $1.09 \mathrm{mg} / \mathrm{g}$ and the highest concentration was in $R$. flava $(3.44 \pm 0.18 \mathrm{mg} / \mathrm{kg})$ and lowest in $A$. bisporus $(0.02 \pm 0.00$ $\mathrm{mg} / \mathrm{kg}$ ). The recommended daily intake for Co is between 0.005 to $0.008 \mathrm{mg}$ (73).

Copper $(\mathrm{Cu})$ is an essential element. Enzymes containing copper are important for the body to transport and use iron (47). Minimum and maximum copper levels were found as $0.17 \pm 0.01 \mathrm{mg} / \mathrm{kg}$ and $9.89 \pm 0.65 \mathrm{mg} / \mathrm{kg}$ for $T$. versicolor and $A$. bisporus. For adults, longterm dietary intake of $\mathrm{Cu}$ at concentrations of 1-10 $\mathrm{mg} /$ day has no apparent adverse effects (64).
Lead $(\mathrm{Pb})$ is used for a number of industrial, domestic, and rural purposes. A significant source of exposure to $\mathrm{Pb}$ is through diet (62). Lead is a cumulative toxin that primarily affects the blood, nervous system, and kidneys. In the blood at high concentrations, $\mathrm{Pb}$ inhibits red blood cell formation and eventually results in anemia (74). The minimum and maximum lead concentration in the mushroom species of this study was in the range of $0.05 \pm 0.00-3.33 \pm 0.06$ $\mathrm{mg} / \mathrm{kg}$. These values were determined in both $P$. torulosus and $M$. graminicola. According to the Joint Food and Agriculture Organization of the United Nations [FAO)/WHO Expert Committee on Food Additives (JECFA)], the provisional tolerable weekly intake of $\mathrm{Pb}$ is $25 \mu \mathrm{g} / \mathrm{kg}$ body weight (75).

\section{CONCLUSION}

Turkey has an appropriate climate for mushroom growth. The studied 16 mushroom species grow naturally in the western part of Turkey. The data obtained in this study show which heavy metals and what amounts are absorbed by edible, inedible, and poisonous mushrooms. The ICP-MS method, with the accuracy verified by comparing the results with the values of certified materials, was successfully applied for the analysis of mushroom species. In this study, the WHO limits were used to compare the safe levels of heavy metals in mushroom species. Accordingly, the heavy metals concentrations in the studied edible mushrooms grown naturally and cultivated in Turkey are at safe levels for public consumption, except Leucoagaricus leucothites. In this mushroom, the $\mathrm{Cr}$ and $\mathrm{Pb}$ levels were slightly over the WHO limits. Moreover, among the inedible mushrooms, the Cr levels in Hebeloma eburneum and Melanoleuca graminicola, and the As levels in Hebeloma fragilipes, exceeded the WHO limits. This

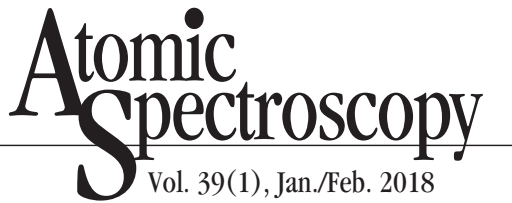

method can also be recommended for use in the routine determination of trace elements in similar matrices. In addition, the study completed the scientific report on the metal concentrations of studied mushroom species.

\section{ACKNOWLEDGMENT}

The authors are thankful to TUBITAK for financial support of the Ph.D. Graduate Scholarships for Turkish Citizens (TUBITAK-BIDEB2211E), the Graduate Scholarship Programme for International Students (TUBITAK-BIDEB-2215), and to Mugla Sitkı Koçman University for technical and instrumental support. Mugla Sitki Koçman University Research Foundation is also acknowledged with project number $15 / 116$.

Received April 10, 2016.

\section{REFERENCES}

1. F.S. Reis, A. Martins and L. Barros, Food Chem. Toxicol. 50, 1201 (2012).

2. P.C.K. Cheung, Mushrooms as functional foods, in P.C.K. Cheung (Ed.), Nutritional value and health benefits of mushrooms, Wiley, Hoboken, NJ, USA, pp. 71 (2008).

3. M. Tüzen, E. Sesli and M. Soylak, Food Control. 18, 806 (2007)

4. M. Tüzen, Microchem. J. 74, 289 (2003).

5. G. Tel, H. Çavdar, E. Deveci, M. Öztürk, M.E. Duru and A. Turkoğlu, Food Addit. Contam. B 7, 226-231 (2014).

L. Rácz and V. Oldal, Microchem. J. 67, 115 (2000).

6. M. Öztürk, M.E. Duru, S. Kivrak, N. Mercan-Dogan, A. Türkoglu and M.A. Özler, Food Chem. Toxicol. 49, 1353 (2011).

7. I. Palacios, M. Lozano, C. Moro, M. D'Arrigo, M.A. Rostagno, J.A. Martinez, A. Garcia-Lafuente, E. Guillamon and A. Villares, Food Chem. 128, 674 (2011). 
8. H.J.C. Froufe, R.M.V. Abreu and I.C.F.R. Ferreira, SAR QSAR Enviro. Res. 20, 579 (2009).

9. B. Aslim and S. Ozturk, J. Med. Food 14, 1419 (2011).

10. K. Gezer, M.E. Duru, I. Kivrak, A. Turkoglu, N. Mercan, H. Turkoglu and S. Gulcan, Afr. J. Biotechnol. 5, 1924 (2006).

11. G. Tel, E. Deveci, S. Kucukaydın, M.A. Özler, M.E. Duru and M. Harmandar, Eurasian J. Anal. Chem. 8,136 (2013).

12. M. Kozarski, A. Klaus, M. Niksic, D. Jakovljevic, J.P.F.G. Helsper and L.J.L.D. Van Griensven, Food Chem. 129, 1667 (2011).

13. I. Orhan and O. Ustun, J. Food Compos. Anal. 24, 386 (2011).

14. T. Xu, R.B. Beelman and J.D. Lambert, Anti-Cancer Agents Med. Chem. 12, 1255 (2012).

15. J. Liu, International Chemical Congress of Pacific Basin Societies, Honolulu, HI, United States, ORGN-488, (December 15-20, 2010).

16. C. Moro, I. Palacios, M. Lozano, M. D'Arrigo, E. Guillamon, A. Villares, J.A. Martinez and A. GarciaLafuente, Food Chem. 130, 350 (2012).

17. M.J. Alves, I.C.F.R. Ferreira, A. Martins and M. Pintado, J. Appl. Microbiol. 113, 466 (2012).

18. H.M.T.B. Hereath, M. Jacob, A.D. Wilson, H.K. Abbas and N.P.D. Nanayakkara, Nat. Prod. Res. 24, 1 (2012).

19. W. Boer, L.B. Folman, G. Klein, J.A. Paulien, T. Svensson, D. Bastviken, G. Oeberg, J.C. Del Rio and L. Boddy, Can. J. Microbiol. 56, 380 (2010).

20. C.C. Lau, N. Abdullah, A.S. Shuib and N. Aminudin, J. Agr. Food Chem. 60, 12341 (2012).

21. M. Kozarski, A. Klaus, M. Niksic, D. Jakovljevic, J.P.F.G. Helsper and L.J.L.D. Van Griensven, Food Chem. 129, 1667 (2011).

22. P.K. Ouzouni and K.A. Riganakos, Acta Aliment. 36, 99 (2007).

23. M. Palanisamy, A. Gil-Ramirez, A. Ruiz-Rodriguez, F.R. Martin, G.
Reglero and C. Soler-Rivas, Int. J. Food Sci. Technol. 47, 1004 (2012)

24. J. Vetter, Eur. Food Res. Technol. 211, 346 (2000).

25. A. Mayer, H. Anke, O.M.A. Sterner, M. Kilian, B. Hoster, O. Sterner and H. Anke, Pesticide Sci. 55, 27 (1999)

26. K. Ohuchi and Y. Aoyagi, J. Jpn. Soc. Food Sci. 57, 532 (2010).

27. D.D. Hu, R.Y. Zhang, G.Q. Zhang, H.X. Wang and T.B. Ng, Phytomedicine 18, 374 (2011).

28. J.P. Yang, T. Hsu, F. Lin, W. Hsu and Y. Chen, Carbohyd. Polym. 90, 174 (2012).

29. L. Rácza, L. Pappb, B. Prokaia and Zs. Kovács, Microchem. J. 54, 444 (1996)

30. Y. Uzun, H. Genccelep, A. Kaya and M.E. Akcay, Ekoloji 20, 6 (2011).

31. P. Mattila, K. Koenkoe, M. Eurola, JM. Pihlava, J. Astola, L. Vahteristo, V. Hietaniemi, J. Kumpulainen, M. Valtonen and V. Piironen, J. Agr. Food Chem. 49, 2343 (2001).

32. M.H. Semreen and H.Y. AboulEnein, Anal. Lett. 44, 932 (2011).

33. O. Isildak, I. Turkekul, M. Elmastas and H.Y. Aboul-Enein, Anal. Lett. 40, 1099 (2007).

34. A. Demirbas, Deut. Lebensmittel Rundschau 99, 62 (2003).

35. N. Dursun, M. Ozcan, K. Musa and O.C. Giyasettin, J. Sci. Food Agr. 86, 1087 (2006).

36. L. Cocchi, L. Vescovi, L.E. Petrini and O. Petrini, Food Chem. 98, 277 (2006).

37. N. Durkan, I. Ugulu, M.C. Unver, Y. Dogan and S. Baslar, Trace Elem. Electroly. 28, 242 (2011).

38. S. Turhan, A. Zararsiz and $\mathrm{H}$. Karabacak, Int. J. Food Prop. 13, 723 (2010).

39. E. Sesli, M. Tuzen and M. Soylak, J. Hazard. Mater. 160, 462 (2008).

40. E. Sesli, Fresen. Environ. Bull. 15, 518 (2006).

41. J.A. Campos, Biol. Trace Elem. Res. 144, 1370 (2011).

42. A. Demirbas, Energ. Edu. Sci. Technol. 7, 67 (2001).
43. F.A. Ayaz, H. Torun, A. Colak, E. Sesli, M. Millson and R.H. Glew, Food Nutr. Sci. 2, 53 (2011).

44. H. Gençcelep, Y. Uzun, Y. Tuncturk and K. Demirel, Food Chem. 113, 1033 (2009).

45. A. Kaya, H. Genccelep, Y. Uzun and K. Demirel, Asian J. Chem. 23, 1099 (2011).

46. E. Sesli, Asian J. Chem. 19, 636 (2007).

47. I. Sen, H. Alli, B. Col, M. Celikkollu and A. Balci, Turk. J. Bot. 36, 519 (2012).

48. M. Konuk, A. Afyon and D. Yagiz, Fresen. Environ. Bull. 16, 1359 (2007).

49. H.H. Dogan, M.A. Sanda, R. Uyanoz, C. Ozturk and U. Cetin, Biol. Trace Elem. Res. 110, 79 (2006).

50. E. Curdova, L. Vavruskova, M. Suchanek, P. Baldrian and J. Gabriel, Talanta 62, 483 (2004).

51. M. Yabanli, Ekoloji. 21, 84 (2012).

52. J. Vetter, Food Chem. 81, 589 (2003).

53. U.S. Department of Agriculture, USDA, U.S. Department of Health and Human Services, Nutrition and your Health: Dietary Guidelines for Americans., 4th ed.. U.S. Dept of Agriculture: Home and Garden Bulletin, Washington, DC, pp. 232 (1995).

55. R.K. Rude, J. Bone Miner. Res. 13, 749 (1998).

56. P. Yi and F. Qin, Biol. Trace Elem. Res. 142, 748 (2011).

57. Z. Yibing, Z. Yong, C. Haifeng, C. Chunyu, G. Jianyou and L. Sha, Biol. Trace Elem. Res. 144, 1351 (2011).

58. World Health Organization, WHO, Chapter 6.12. Vanadium Air Quality Guidelines - Second Edition Regional Office for Europe, Copenhagen, Denmark, pp. 2 (2000).

59. World Health Organization, WHO, Trace elements in human nutrition: Manganese. Report of a WHO expert committee. Geneva, Switzerland (Technical Report Series No. 532), pp. 34-36 (1973).

60. M. Tüzen and M. Soylak, Food Chem. 102, 1089 (2007). 


\section{Atomic $_{\text {Spectroscopy }}^{\text {to }}$ \\ 1 Vol. 39(1), Jan./Feb. 2018}

61. National Research Council (NRC). Recommended dietary allowances, 10th ed. Washington, DC, USA, National Academy Press, 1989.

62. A. Çayır, M. Coşkun and M. Coşkun, Biol. Trace Elem. Res. 134, 212 (2010).

63. A.H. Shankar and A.S. Prasad, Am. J. Clin. Nutr. 68, 447 (1998).

64. World Health Organization, WHO, Guidelines for drinking-water quality, 2nd ed., Vol. 2. Health criteria and other supporting information. Geneva, Switzerland (1996).

65. T.C. Stadtman, Annu. Rev. Biochem. 59, 111 (1990).

66. FAO/WHO, Preparation and use of food-based dietary guidelines. Report of a joint FAO/WHO consultation. Geneva, Switzerland, WHO Technical Report Series, No. 880 (1998).

67. World Health Organization, WHO, Aluminium. Geneva, Switzerland, International Programme on Chemical Safety (Environmental Health Criteria 194), (1997)

68. E.J. Underwood, Trace elements in human and animal nutrition (4th Ed.). New York, USA, Academic Press, (1977).

69. Institute of Medicine, Food and Nutrition Board, Dietary Reference Intakes for Vitamin A, Vitamin K, Arsenic, Boron, Chromium, Copper, Iodine, Iron, Manganese, Molybdenum, Nickel, Silicon, Vanadium, and Zinc, Standing Committee on the Scientific Evaluation of Dietary Reference Intakes, Food and Nutrition Board, Institute of Medicine. National Academy Press, 773 p. Washington, DC, USA (2001).

70. J. Vetter, Eur. Food Res. Technol. 219, 71 (2004).

71. World Health Organization, WHO, Guidelines for the assessment of herbal medicines, Munich, Germany (1991).

72. World Health Organization, WHO, Cobalt and inorganic cobalt compounds. Geneva, Switzerland (2006).

73. M.V. Dimitrijevic, V.D. Mitic, J.S. Cvetkovic, V.P.S. Jovanovic, J.J.
Mutic and S.D.N. Mandic, Eur. Food Res. Technol. 242,1 (2016).

74. World Health Organization, WHO, Evaluation of certain food additives and contaminants, In Thirty-third report of the Joint FAO/WHO Expert Committee on food additives, Geneva, Switzerland, 776, 26 (1989).

75. World Health Organization, WHO, Preventing disease through healthy environments, exposure to lead: A major public health concern, Geneva, Switzerland (2006).

76. WHO, Guideline for Drinking-Water Quality, fourth ed., World Health Organization, Geneva, Switzerland (2011). 